\title{
PENGARUH KUALITAS PRODUK, KUALITAS PELAYANAN, DAN HARGA TERHADAP KEPUTUSAN PEMBELIAN MOBIL MITSUBISHI PADA PT. SARDANA INDAH BERLIAN MOTOR MEDAN
}

\author{
Hardy Utama ${ }^{1}$, David Tandreas ${ }^{2}$, Andre Fernandes Riady ${ }^{3}$, Hardy Wijaya ${ }^{4}$, Charles Harry Faska Gultom ${ }^{5}$, \\ Melkyory Andronicus ${ }^{6}$ \\ Faculty of Economy, Universitas Prima Indonesia, Medan, Indonesia \\ andromelki@gmail.com
}

\begin{abstract}
This research was conducted in PT. Sardana Indah Berlian Motor Medan. The purpose of this study was to examine and analyze the effect of product quality, service quality and price on purchasing decisions for Mitsubishi cars in PT. Sardana Indah Berlian Motor Medan. The decision to buy Mitsubishi cars has decreased. This research method uses quantitative methods. The population in this study amounted to 1376 customers and the sample amounted to 93 customers. The sampling technique of this research is simple random sampling. Testing the hypothesis partially obtained the value of $t_{\text {count }}-0.710<1.987$ and the significance obtained is $0.480>0.05$, meaning that $H_{0}$ is accepted and $H_{a}$ is rejected, namely partially Product Quality has no significant effect on purchasing decisions for Mitsubishi cars in PT. Sardana Indah Berlian Motor Medan. Testing the hypothesis partially obtained the value of $t_{\text {count }}-0.062<1.987$ and the significance obtained is $0.951>0.05$, meaning that $H_{0}$ is accepted and $H_{a}$ is rejected, namely partially Service Quality has no significant effect on purchasing decisions for Mitsubishi cars in PT. Sardana Indah Berlian Motor Medan. Testing the hypothesis partially obtained the value of tcount $-0.91<1.987$ and the significance obtained is $0.928>0.05$, meaning that $H_{0}$ is accepted and $H_{a}$ is rejected that is partially the price has no significant effect on purchasing decisions for Mitsubishi cars in PT. Sardana Indah Berlian Motor Medan. The results of the simultaneous test are $F_{\text {count }}=0.168<F_{\text {table }} 2.71$ and the significance probability is $0.918>0.05$. It can be concluded that $H_{0}$ is accepted and $H_{a}$ is rejected, namely simultaneously Product Quality, Service Quality and Price have no significant effect on the Mitsubishi Car Purchase Decision variable in PT. Sardana Indah Berlian Motor Medan.
\end{abstract}

Keywords: Distribution Channels, Service Quality, Price, Purchasing Decision.

\section{PENDAHULUAN}

Saat ini banyak sekali merek mobil yang ditawarkan, beberapa merek yang cukup dikenal oleh banyak orang dan membanjiri pasar di Indonesia adalah Toyota, Daihatsu, Honda, Suzuki dan Mitsubishi. Penelitian ini dilakukan pada PT. Sardana Indah Berlian Motor yang lebih dikenal dengan sebutan "Sardana Berlian”, yang merupakan dealer mobil merek MITSUBISHI di Kota Medan Sumatera Utara.

Tabel 1. Data Penjualan Mobil Mitsubishi 2020

\begin{tabular}{|c|c|c|}
\hline \multirow{2}{*}{ Bulan } & $\begin{array}{c}\text { Target Penjualan } \\
\text { Mobil (unit) }\end{array}$ & $\begin{array}{c}\text { Realisasi Penjualan } \\
\text { Mobil (Unit) }\end{array}$ \\
\hline Januari & 60 & 73 \\
\cline { 2 - 3 } Februari & 80 & 66 \\
\hline \multirow{2}{*}{ Maret } & 85 & 60 \\
April & 85 & 58 \\
\cline { 2 - 3 } Mei & 90 & 55 \\
\cline { 2 - 3 } Juni & 120 & 88 \\
\cline { 2 - 3 } Juli & 110 & 74 \\
\cline { 2 - 3 } Agustus & 95 & 65 \\
\cline { 2 - 3 } September & 90 & 59 \\
\hline Oktober & 90 & 60 \\
\cline { 2 - 3 } November & 110 & 82 \\
\cline { 2 - 3 } Desember & 120 & 86 \\
\hline
\end{tabular}


Sumber : PT. Sardana Indah Berlian Motor Medan

Dari Tabel 1 memperlihatkan data penjualan mobil merek Mitsubishi pada PT. Sardana Indah Berlian Motor Medan pada bulan Januari berhasil memenuhi target penjualan sebanyak 60 unit dengan realisasi penjualan 73 unit, dikarenakan adanya promo diskon besar (promo cuci gudang) untuk menghabiskan sisa stock unit tahun 2019. Namun sayangnya pada bulan seterusnya hingga bulan Desember tidak ada yang berhasil memenuhi target penjualan. Melihat kondisi ini, dapat di simpulkan bahwa PT. Sardana Indah Berlian Motor Medan mengalami kesulitan menjual mobil merek Mitsubishinya.

Tabel 2. Data Keluhan Pelanggan Terhadap 2 Tipe Mobil Mitsubishi

\begin{tabular}{|c|c|c|c|c|}
\hline \multirow[b]{2}{*}{ Bulan } & \multicolumn{2}{|r|}{ Pajero Sport } & \multicolumn{2}{|r|}{ X-Pander } \\
\hline & $\begin{array}{l}\text { Banyak } \\
\text { Keluhan }\end{array}$ & Hal yang dibahas & $\begin{array}{l}\text { Banyak } \\
\text { Keluhan }\end{array}$ & Hal yang dibahas \\
\hline Jan & 1 & Desain lampu belakang yang kurang menarik & 2 & RPM mesin kurang stabil, AC kurang dingin \\
\hline Feb & 1 & Kabin mobil sempit & 3 & $\begin{array}{l}\text { Jok mudah kotor, lampu depan kurang terang, rem } \\
\text { bergetar saat digunakan pada kecepatan tinggi }\end{array}$ \\
\hline Mar & 2 & $\begin{array}{l}\text { Desain lampu belakang yang kurang menarik, Tarikan } \\
\text { awal yang sedikit lambat }\end{array}$ & 4 & $\begin{array}{l}\text { RPM mesin kurang stabil, Tarikan awal lambat, lampu } \\
\text { depan redup, kampas kopling cepat habis }\end{array}$ \\
\hline Apr & 1 & Lampu DRL (Daytime Running Light) cepat redup & 3 & $\begin{array}{l}\text { Ban depan agak berisik saat melintasi jalan berlubang, } \\
\text { Jok mudah kotor, RPM mesin kurang stabil }\end{array}$ \\
\hline Mei & 1 & Kesulitan membuka pintu belakang & 2 & Lampu depan kurang terang, RPM mesin kurang stabil \\
\hline Jun & 2 & $\begin{array}{l}\text { Kaki-kaki mobil sering bermasalah, tidak ada penutup } \\
\text { ban cadangan dibagian bawah }\end{array}$ & 2 & $\begin{array}{l}\text { RPM mesin kurang stabil, Kaca mobil bergetar saat } \\
\text { dibuka dan ditutup }\end{array}$ \\
\hline Jul & 3 & $\begin{array}{l}\text { Bagasi belakang sempit, Shock Breaker mudah rusak, } \\
\text { Desain lampu kurang menarik }\end{array}$ & 3 & $\begin{array}{l}\text { Mobil kurang bertenaga saat jalan menanjak, RPM } \\
\text { mesin kurang stabil, AC kurang dingin }\end{array}$ \\
\hline Agu & 1 & Cara melipat bangku belakang yang sangat ribet & 1 & RPM mesin kurang stabil \\
\hline Sep & 1 & $\begin{array}{l}\text { Tempat duduk bagian belakang baris ke } 3 \text { kurang } \\
\text { nyaman karena agak sempit }\end{array}$ & 3 & $\begin{array}{l}\text { Interior mudah kotor, Kampas kopling cepat habis, } \\
\text { Pedal rem bergetar saat di rem pada kecepatan tinggi }\end{array}$ \\
\hline Okt & 3 & $\begin{array}{l}\text { Lampu DRL cepat redup, Desain lampu belakang tidak } \\
\text { menarik, Kaki-kaki sering bermasalah }\end{array}$ & 2 & Jok mudah kotor, AC kurang dingin \\
\hline Nov & 4 & $\begin{array}{l}\text { Desain lampu belakang tidak menarik, Kaki-kaki sering } \\
\text { bermasalah, Shock breaker cepat rusak, Tarikan awal } \\
\text { sedikit lambat }\end{array}$ & 3 & $\begin{array}{l}\text { RPM mesin kurang stabil, Shock mudah bocor, } \\
\text { Tarikan kurang kuat }\end{array}$ \\
\hline Des & 2 & $\begin{array}{l}\text { Bagasi belakang sempit, Desain lampu belakang } \\
\text { kurang menarik }\end{array}$ & 2 & $\begin{array}{l}\text { Lampu depan kurang terang, Kaca mobil bergetar saat } \\
\text { dibuka dan ditutup }\end{array}$ \\
\hline
\end{tabular}

Sumber : PT. Sardana Indah Berlian Motor Medan

Dari Tabel 2 dapat dilihat bahwa mobil merek Mitsubishi memiliki beberapa kekurangan pada bagian sparepart atau body mobil yang diketahui melalui keluhan dan kritik dari konsumen di setiap bulannya baik yang sudah membeli dan menggunakan maupun hanya sekedar memberikan kritikan terhadap mobil merek Mitsubishi. 
Tabel 3. Data Keluhan Kualitas Pelayanan

\begin{tabular}{|c|c|c|}
\hline \multicolumn{3}{|r|}{ Tabel Kualitas Pelayanan } \\
\hline Bulan & $\begin{array}{l}\text { Banyak } \\
\text { keluhan }\end{array}$ & Hal yang dibahas \\
\hline Jan & 1 & Permintaan data pembeli yang terlalu banyak \\
\hline Feb & 1 & Sales kurang bisa menjelaskan produk \\
\hline Mar & 2 & $\begin{array}{c}\text { Sales kurang bertanggung jawab, Respon sales yang } \\
\text { sangat lambat }\end{array}$ \\
\hline Apr & 1 & Surat-surat mobil lama keluarnya \\
\hline Mei & 1 & Sales kurang bersemangat melayani \\
\hline Jun & 1 & Pembelian kredit lama prosedurnya \\
\hline Jul & 1 & Pelayanan untuk service pelanggan kurang \\
\hline Agu & 2 & Sales kurang ramah, sales tidak informatif \\
\hline Sep & 3 & $\begin{array}{l}\text { Indent sparepart cukup makan waktu, Sales kurang } \\
\text { profesional, Permintaan data pembeli sangat banyak }\end{array}$ \\
\hline Okt & 3 & $\begin{array}{c}\text { Informasi yang diberikan sales kurang jelas, Promo } \\
\text { kurang menarik, Respon sales kurang cepat }\end{array}$ \\
\hline Nov & 1 & Lamanya prosedur untuk pembelian dengan kredit \\
\hline Des & 1 & Sales menjelaskan terlalu cepat \\
\hline
\end{tabular}

Sumber : PT. Sardana Indah Berlian Motor Medan

Dari Tabel 3 memperlihatkan bahwa perusahaan PT. Sardana Indah Berlian Motor Medan memiliki kekurangan dibidang pelayanan yang dibuktikan dari diterimanya keluhan dan kritik mengenai pelayanan yang diterima konsumen disetiap bulannya.

Tabel 4. Perbandingan Harga

\begin{tabular}{|c|c|c|c|c|c|}
\hline \multicolumn{2}{|c|}{ Mitsubishi } & \multicolumn{2}{c|}{ Toyota } & \multicolumn{2}{c|}{ Nissan } \\
\hline Pajero Sport & Rp.732.500.000 & Fortuner & Rp.703.600.000 & Terra & Rp.680.200.000 \\
\hline X-Pander & Rp.288.500.000 & Rush & Rp.282.950.000 & Livina & Rp.284.000.000 \\
\hline
\end{tabular}

Sumber : PT. Sardana Indah Berlian Motor Medan

Dari Tabel 4 dapat dilihat bahwa dari 3 (tiga) merek mobil yaitu Mitsubishi, Toyota dan Nissan yang masing-masing mengambil 2 (dua) contoh sampel produk di kelas yang sama atau memiliki kemiripan dalam segi kualitas, dapat dilihat bahwa produk mobil Mitsubishi memiliki harga yang lebih mahal dibandingkan dengan kedua harga dari produk merek lain. Sehingga dapat membuat calon konsumen berpikir untuk membeli dikarenakan banyak kompetitor yang menjual barang berkualitas serupa dengan harga yang lebih murah. 


\section{KAJIAN LITERATUR}

\section{Keputusan Pembelian}

Menurut Kotler \& Amstrong (2014), keputusan pembelian adalah tahap dalam proses pengambilan keputusan pembeli di mana konsumen benar-benar membeli. Perilaku keputusan pembelian sangat berbeda untuk masing-masing produk. Keputusan yamg lebih kompleks biasanya melibatkan peserta pembelian dan pembelian yang lebih banyak. Menurut Sunyoto (2013:85). Indikator keputusan pembelin terdiri dari:

1. Keputusan tentang jenis produk

2. Keputusan tentang bentuk produk

3. Keputusan tentang merk

4. Keputusan tentang penjualnya

5. Keputusan tentang jumlah produk

6. Keputusan tentang waktu pembelian

7. Keputusan tentang cara pembelian

\section{Kualitas Produk}

Menurut Tjiptono (2012), kualitas produk adalah tingkat mutu yang diharapkan dan pengendalian keragaman dalam mencapai mutu tersebut untuk memenuhi kebutuhan konsumen.

Menurut Gaspersz (2008), dimensi kualitas produk adalah sebagai berikut:

1. Kinerja (performance)

2. Keandalan (reliability)

3. Keistimewaan tambahan (feature)

4. Daya tahan (durability)

5. Estetika (Aesthethics)

\section{Kualitas Pelayanan}

Menurut Rambat Lupiyadi (2012), kualitas layanan adalah seberapa jauh perbedaan antara kenyataan dan harapan pelanggan atas layanan yang mereka terima/peroleh. Kualitas pelayanan harus dimulai dari kebutuhan pelanggan/nasabah dan berakhir dengankepuasan pelanggan serta dapat mempengaruhi dari loyalitas pelanggan/nasabah.

Tjiptono dan Chandra mengidentifikasikan ada 10 indikator kualitas pelayanan, yang dirangkum menjadi 5 indikator yaitu:

1. Reliabilitas (realiability)

2. Daya Tanggap (responsiveness)

3. Jaminan (assurance)

4. Empati (empathy)

5. Bukti Fisik (tangibles)

\section{Harga}

Menurut Kotler dan Armstrong (2013:314), Harga adalah sejumlah uang yang dibebankan atas suatu produk atau jasa atau jumlah dari nilai yang ditukar konsumen atas manfaat-manfaat karena memiliki atau menggunakan produk atau jasa tersebut.

Menurut Kotler dan Armstrong (2008:278) ada empat indikator yang mencirikan harga yaitu:

1. Keterjangkauan harga

2. Kesesuaian harga dengan kualitas produk

3. Daya saing harga

4. Kesesuaian harga dengan manfaat

\section{Teori Pengaruh Kualitas Produk Terhadap Keputusan Pembelian}

Menurut Tjiptono (2008:25), kualitas produk merupakan perpaduan antara sifat dan karakteristik yang menentukan sejauh mana keluaran dapat memenuhi prasyarat kebutuhan pelanggan atau menilai sampai seberapa jauh sifat dan karakteristik itu memenuhi kebutuhannya, kualitas produk mempunyai delapan faktor yaitu Performance (kinerja), Durability (daya tahan), Conformance to specifications (kesesuaian dengan spesifikasi), Features (fitur), Reliability (reliabilitas), Aesthetics (estetika), Perceived quality (kesan kualitas), dan Serviceability (kemampuan layanan). 


\section{Teori Pengaruh Kualitas Pelayanan Terhadap Keputusan Pembelian}

Kualitas pelayanan merupakan tingkat keunggulan yang diharapkan dan pengendalian atas tingkat keunggulan tersebut untuk memenuhi keinginan konsumen. Apabila jasa atau pelayanan yang diterima atau dirasakan sesuai dengan yang diharapkan, maka kualitas jasa atau pelayanan dipersepsikan baik dan memuaskan. Jika jasa atau pelayanan yang diterima melampaui harapan konsumen, maka kualitas jasa atau pelayanan dipersepsikan sebagai kualitas yang ideal. Sebaliknya jika jasa atau pelayanan yang diterima lebih rendah daripada yang diharapkan, maka kualitas jasa atau pelayanan dipersepsikan buruk (Tjiptono, 2009).

\section{Teori Pengaruh Harga Terhadapa Keputusan Pembelian}

Menurut Basu Swastha harus dibayar oleh konsumen atau pembeli untuk mendapatkan produk yang ditawarkan oleh penjual. Penetapan harga jual harus disesuaikan dengan daya beli konsumen yang dituju dan dengan mempertimbangkan faktor biaya, laba, pesaing, dan perubahan keinginan pasar

\section{Kerangka Konseptual}

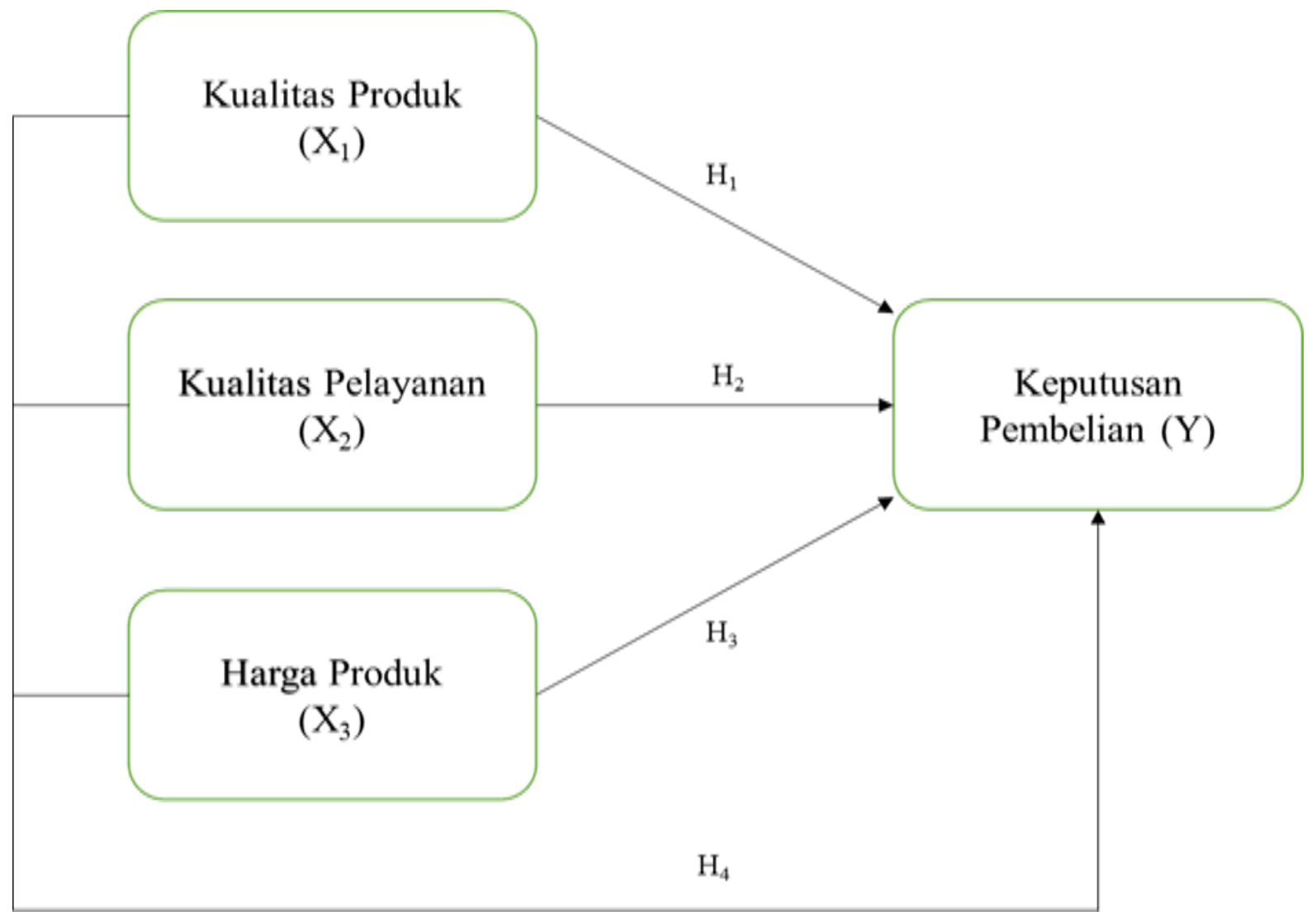

\section{Gambar 1 Kerangka Konseptual}

\section{METODE}

\section{Lokasi dan Waktu Penelitian}

Penelitian ini dilakuan dilokasi PT.Sardana Indah Berlian Motor, Jalan Lintas Sumatra, Ujung Serdang, Tj. Morawa, Kabupaten Deli Serdang, Sumatera Utara 20362, Medan. Waktu penelitan dilakukan dari bulan Januari 2020 sampai dengan bulan Mei 2021.

\section{Pendekatan Penelitian}

Pendekatan dalam penelitian ini adalah pendekatan kuantitatif, yaitu penelitian yang menekankan analisisnya pada data-data numerical (angka) yang diolah dengan metode statistika. Pada dasarnya, pendekatan kuantitatif di lakukan pada penilitian inferensial (dalam rangka pengujian hipotesis) dan 
menyandarkan kesimpulan hasilnya pada suatu probabilitas kesalahan penolakan hipotesis nihil. Dengan metode kuantitatif akan diperoleh signifikansi perbedaan kelompok atau signifikansi hubungan antar variable yang ditelilti. Pada umumnnya, penelititian kuantitatif merupakan penelitian sampel besar

\section{Jenis Penelitian}

Dalam penelitian ini, peneliti menggunakan metode penelitian kuantitatif yang menggunakan populasi atau sampel untuk meneliti. Data dikumpulkan dengan menggunakan instrumen atau alat ukur, kemudian dianalisis dengan statistik atau secara kuantitatif.

Hasil metodologi penelitian kuantitatif berupa hipotesis. Instrumen, statistik, dan hipotesis pada umumnya ditemukan pada:

1. Survei

Metode survei digunakan untuk mendapatkan data tentang karakteristik sesuatu. Metode ini juga digunakan untuk menguji beberapa hipotesis atas sampel yang diambil dari suatu populasi. Teknik pengumpulan data adalah dengan kuisioner atau wawancara. Hasil dari metodologi penelitian ini berupa generalisasi.

2. Eksperimen

Metode eksperimen digunakan untuk mengetahui pengaruh variabel independen (perlakuan/treatment) terhadap variabel dependen (hasil) dalam kondisi yang dikendalikan. Agar kondisi dapat dikendalikan, dalam penelitian eksperimen dibutuhkan kelompok kontrol. Metodologi penelitian ini sering dilakukan di laboratorium.

\section{Sifat Penelitian}

Sifat penelitian yang diggunakan adalah deskriptif expkanatory. Menurut Singarimbun dalam Singarimbun dan Effendi (Ed 1995) menyatakan bahwa penelitian eksplanatori adalah penelitian yang menjelaskan keterkaitan kausal antar variabel penelitian melalui pengujian hipotesis. Didalam penelitian eksplanatori, pendekatan yang dipakai dalam penelitian ini adalah metode survei, yaitu penelitian yang dilakukan untuk memperoleh fakta-fakta mengenai fenomena-fenomena yang ada didalam objek penelitian dan mencari keterangan secara aktual dan sistematis.

\section{Populasi dan Sampel}

Jumlah populasi dalam penelitian ini adalah sebanyak 1326 pelanggan, sehingga presentase kelonggaran yang digunakan adalah $10 \%$ dan hasil perhitungan dapat dibulatkan untuk mencapai kesesuaian. Maka untuk mengetahui sampel penelitian, dengan perhitungan sebgai berikut:

$$
\begin{gathered}
n=1376 /(1+1376(10 \%) 2 \\
n=93,22 \approx 93 \text { Responden }
\end{gathered}
$$

Sampel dalam penelitian ini berjumlah 93 pelanggan dan 30 pelanggan diluar sampel dijadikan responden untuk pengujian validitas dan realibilitas.

\section{Uji Asumsi Klasik}

\section{Uji Normalitas}

Menurut Surjaweni (2014:52) uji normalitas bertujuan untuk Mengetahui distribusi data dalam variabel yang akan digunakan dalam penelitian. Data yang baik dan layak digunakan dalam penelitian adalah data yang memiliki distribusi normal. Normalitas data dapat dilihat dengan mengunakan uji normal Kolmogorov smirnov yaitu :

1. Jika sig $>0,05$ maka berdistribusi normal

2. Jika sig $<0,05$ maka berdistribusi tidak normal

\section{Uji Multikolinieritas}

Menurut Surjaweni (2014:185) uji multikolineartitas diperlukan untuk mengetahui ada tidaknya variabel independen yang memilki kemiripan antar variable independen dalam suatu model. Jika VIF yang dihasilkan diantara 1-10 maka tidak terjadi multikolinearitas. 
Multikolineriaritas dapat juga dilihat dari (1) nilai Tolerance dan lawannya (2) variance inflation factor (VIF). Tolerance mengukur variabilitas variable independent yang terpilih yang tidak dijelaskan oleh variable independent lainnya

\section{Uji Heteroskedastisitas}

Menurut Surjaweni (2014:186) uji heteroskedastisitas bertujuan menguji perbedaan variance residual suatu periode pengamatan ke periode pengamatan yang lain. Cara memprediksi ada tidaknya heterodkedastisitas pada suatu model dapat dilihat dengan pola gambar scatterplot, regresi yang tidak terjadi heteroskedastisitas jika :

1. Titik-titik data menyebar di atas dan di bawah atau di sekitar angka 0 .

2. Titik-titik data tidak mengumpulkan hanya di atas atau di bawah saja.

3. Penyebaran titik-titik data tidak boleh membentuk pola bergelombang melebar kemudian menyempit dan melebar kembali.

4. Penyebaran titik-titik data tidak berpola

Uji Glejser, yaitu jika nilai signifikan lebih besar dari 0,05 maka pada model regresi tidak terjadi masalah heteroskedastisitas.

\section{Pengujian Hipotesis}

Pengujian Hipotesis Secara Simultan (Uji F)

Menurut Sunyoto (2014:119) uji F digunakan untuk mengetahui pengaruh antara variabel independen terhadap variabel dependen secara bersama-sama.

Uji hipotesis dilakukan dengan SPSS versi IBM SPSS Statistics 28.0.0.0. Dalam penelitian ini nilai $F_{\text {hitung }}$ akan dibandingkan dengan nilai $\mathrm{F}_{\text {tabel}}$, dengan kriteria pengambilan keputusannya adalah :

1. $\mathrm{H}_{0}: \beta_{1}, \beta_{2}, \beta_{3}=0$ (variabel bebas secara simultan tidak berpengaruh terhadap keputusan pembelian pada variabel terikat)

2. $\mathrm{H}_{\mathrm{a}}: \beta 1, \beta_{2}, \beta_{3} \neq 0$ (variabel bebas secara simultan berpengaruh terhadap variabel terikat)

Dalam penelitian ini $F_{\text {hitung }}$ akan dibandingkan dengan $F_{\text {tabel }}$ pada tingkat signifikansi $(\alpha)=5 \%$. Kriteria penelitian hipotesis pada uji $\mathrm{F}$ ini adalah:

1. $\mathrm{H}_{0}$ diterima apabila $\mathrm{F}_{\text {hitung }} \leq \mathrm{F}_{\text {tabel }}$ untuk tingkat signifikan $\alpha=5 \%$

2. $\mathrm{H}_{\mathrm{a}}$ diterima apabila $\mathrm{F}_{\text {hitung }}>\mathrm{F}_{\text {tabel }}$ untuk tingkat signifikan $\alpha=5 \%$

\section{Pengujian Hipotesis Secara Parsial (Uji t)}

Menurut Sunyoto (2014:118) uji t digunakan untuk mengetahui ada tidaknya hubungan atau pengaruh yang berarti (signifikan) antara variabel independen secara parsial terhadap variabel dependen dengan ketentuan:

1. $\mathrm{H}_{0}: \beta_{1}, \beta_{2}, \beta_{3}=0$ (variabel bebas secara parsial tidak berpengaruh terhadap variabel terikat)

2. $H_{\mathrm{a}}: \beta_{1}, \beta_{2}, \beta_{3} \neq 0$ (variabel bebas secara parsial berpengaruh terhadap variable terikat)

Dalam penelitian ini nilai $t_{\text {hitung }}$ akan dibandingkan dengan nilai $t_{\text {tabel, }}$, dengan kriteria pengambilan keputusannya adalah:

1. $\mathrm{H}_{0}$ diterima apabila $\mathrm{t}_{\text {tabel }} \leq \mathrm{t}_{\text {hitung }} \leq \mathrm{t}_{\text {tabel }}$ (dengan tingkat signifikan $\left.\alpha=5 \%\right)$

2. $\mathrm{H}_{\mathrm{a}}$ diterima apabila $\mathrm{t}_{\text {hitung }}<-\mathrm{t}_{\text {tabel }}$ atau $\mathrm{t}_{\text {hitung }}>\mathrm{t}_{\text {tabel }}$ (dengan tingkat signifikan $\alpha=5 \%$ )

\section{HASIL DAN DISKUSI}

\section{Uji Asumsi Klasik}

\section{Uji Normalitas}

A. Hasil pengujian normalitas Histogram yaitu : 


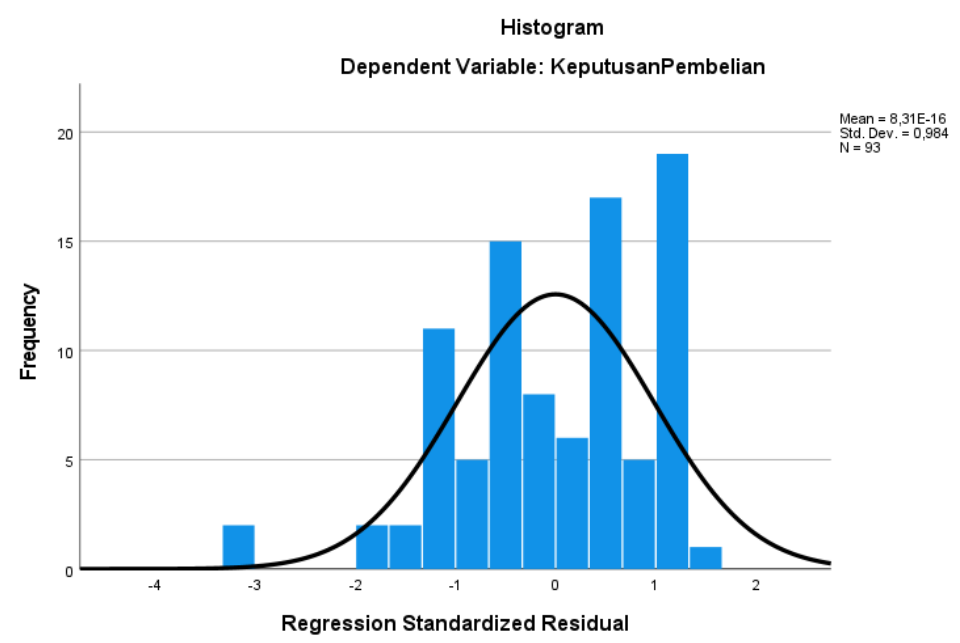

Gambar 1 Uji Normalitas Histogram

Sumber : Data SPSS, 2021

Grafik histogram dari Gambar 2 menunjukkan bahwa data rill membentuk garis kurva cenderung simetri (U) tidak melenceng ke kiri ataupun kekanan maka dapat dikatakan data berdistribusi normal.

B. Berikut ini adalah hasil Uji Normalitas P-P Plot :

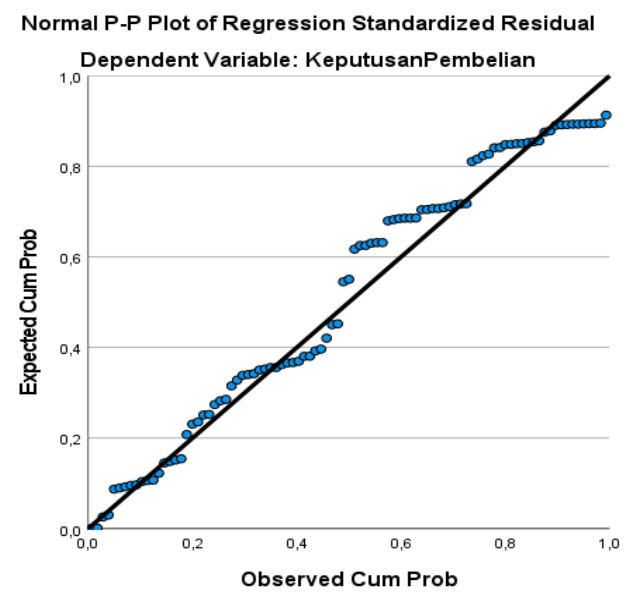

Gambar 2 Uji Normalitas P-P Plot

Sumber : Data SPSS, 2021

Grafik Normalitas P-P Plot dari Gambar 3 menghasilkan data yang menyebar disekitar garis diagonal, penyebarannya sebagian besar mendekati garis diagonal. Hal ini berarti bahwa data berditribusi normal.

\section{Uji Normalitas Kolmogorov Smirnov}

Berikut ini adalah hasil Uji Normalitas Kolmogorov Smirnov : 
Tabel 5. Uji Normalitas Kolmogorov Smirnov

One-Sample Kolmogorov-Smirnov Test

\begin{tabular}{|c|c|c|c|}
\hline & & & $\begin{array}{l}\text { Unstandardiz } \\
\text { ed Residual }\end{array}$ \\
\hline N & & & 93 \\
\hline \multirow[t]{2}{*}{ Normal Parameters ${ }^{a, b}$} & \multicolumn{2}{|l|}{ Mean } &, 0000000 \\
\hline & \multicolumn{2}{|l|}{ Std. Deviation } & 4,28140090 \\
\hline \multirow[t]{3}{*}{ Most Extreme Differences } & \multicolumn{2}{|l|}{ Absolute } &, 114 \\
\hline & \multicolumn{2}{|l|}{ Positive } &, 090 \\
\hline & \multicolumn{2}{|l|}{ Negative } &,- 114 \\
\hline \multicolumn{3}{|l|}{ Test Statistic } &, 114 \\
\hline \multicolumn{3}{|l|}{ Asymp. Sig. (2-tailed) ${ }^{c}$} &, 005 \\
\hline \multirow{3}{*}{$\begin{array}{l}\text { Monte Carlo Sig. (2- } \\
\text { tailed) }\end{array}$} & Sig. & &, 004 \\
\hline & \multirow[t]{2}{*}{$99 \%$ Confidence Interval } & Lower Bound &, 003 \\
\hline & & Upper Bound &, 006 \\
\hline
\end{tabular}
a. Test distribution is Normal.
b. Calculated from data.
c. Lilliefors Significance Correction.
d. Lilliefors' method based on 10000 Monte Carlo samples with starting seed 2000000

Sumber : Data SPSS, 2021

Berdasarkan Tabel 5 diperoleh hasil uji normalitas nilai signifikansi $0,05=0,05$, maka dapat disimpulkan bahwa nilai residual berdistribusi normal.

\section{Uji Multikolinearitas}

Multikolineritas dapat juga dilihat dari nilai tolerance dan variance inflation factor (VIF). Berikut hasil pengujian multikolinearitas yaitu:

\section{Uji Multikolinearitas}

\section{Tabel 6. Uji Multikolinearitas}

\begin{tabular}{|c|c|c|c|c|c|c|c|c|}
\hline \multicolumn{9}{|c|}{ Coefficients $^{a}$} \\
\hline \multirow[b]{2}{*}{ Model } & & \multicolumn{2}{|c|}{$\begin{array}{l}\text { Unstandardized } \\
\text { Coefficients }\end{array}$} & \multirow{2}{*}{$\begin{array}{l}\text { Standardized } \\
\text { Coefficients } \\
\text { Beta } \\
\end{array}$} & \multirow[b]{2}{*}{$\mathrm{t}$} & \multirow[b]{2}{*}{ Sig. } & \multicolumn{2}{|c|}{ Collinearity Statistics } \\
\hline & & & $\begin{array}{l}\text { Std. } \\
\text { Error }\end{array}$ & & & & Tolerance & VIF \\
\hline 1 & (Constant) & 24,197 & 5,708 & & 4,239 & $<, 001$ & & \\
\hline & KualitasProduk &,- 127 & , 178 &,- 076 &,- 710 & ,480 & ,984 & 1,017 \\
\hline & $\begin{array}{l}\text { KualitasPelayana } \\
\mathrm{n}\end{array}$ & ,011 & 171 & 007 & ,062 & 951 & ,992 & 1,008 \\
\hline & Harga &,- 017 & 183 &,- 010 &,- 091 & ,928 & ,987 & 1,013 \\
\hline
\end{tabular}

a. Dependent Variable: KeputusanPembelian

Sumber : Data SPSS, 2021 
Tabel 6 menunjukkan bahwa nilai tolerance $>0,1$ dengan nilai Kualitas Produk $(0,984)$, Kualitas Pelayanan (0,992), Harga (0,987). Nilai VIF menunjukkan $<10$ untuk Kualitas Produk $(1,017)$, Kualitas Pelayanan $(1,008)$, Harga $(1,013)$ yang berarti bahwa dalam penelitian ini tidak terjadi multikolinearitas.

\section{Uji Heteroskedastisitas}

Uji Heteroskedastisitas bertujuan untuk menguji perbedaan variance residual suatu periode pengamatan ke periode pengamatan lainnya.

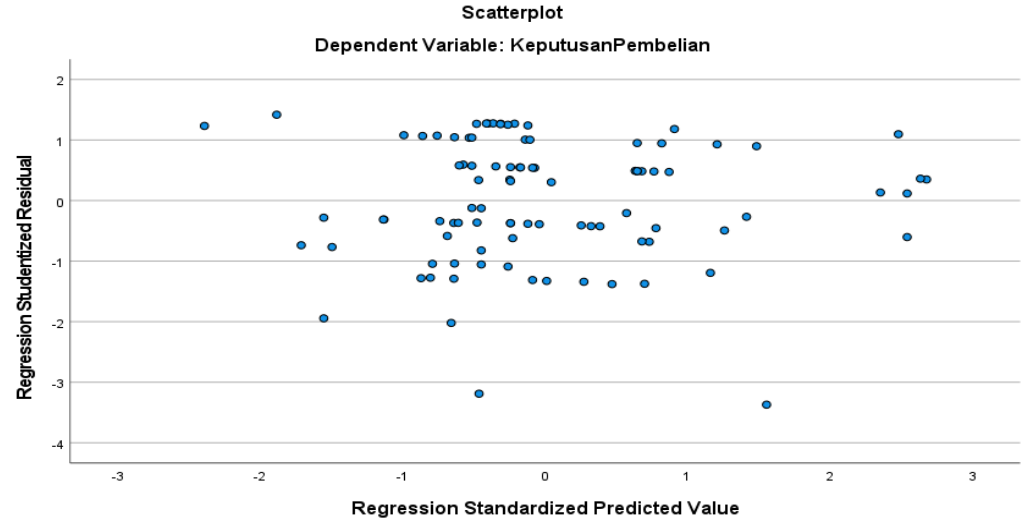

Gambar 3 Uji Heteroskedastisitas

Sumber : Data SPSS, 2021

Uji Heteroskedastisitas dari Gambar 4 terlihat bahwa pola titik yang menyebar tidak jelas di bagian atas maupun dibawah angka nol (0) pada sumbu Y, dan tidak berkumpul di satu tempat, sehingga dalam grafik scatterplot dapat disimpulkan bahwa tidak terjadi heteroskedastisitas pada model regresi.

\section{Uji Gletjer}

\section{Tabel 7. Uji Gletjer}

\begin{tabular}{|c|c|c|c|c|c|c|}
\hline \multicolumn{7}{|c|}{ Coefficients $^{a}$} \\
\hline & & \multicolumn{2}{|c|}{ Unstandardized Coefficients } & \multirow{2}{*}{$\begin{array}{c}\text { Standardized } \\
\text { Coefficients } \\
\text { Beta }\end{array}$} & \multirow[b]{2}{*}{$\mathrm{t}$} & \multirow[b]{2}{*}{ Sig. } \\
\hline \multicolumn{2}{|c|}{ Model } & $\mathrm{B}$ & Std. Error & & & \\
\hline \multirow[t]{4}{*}{1} & (Constant) &,- 154 & 3,115 & &,- 050 & 961 \\
\hline & KualitasProduk &, 139 & 097 &, 150 & 1,423 &, 158 \\
\hline & KualitasPelayanan &,- 021 & 093 &,- 024 &,- 228 & 820 \\
\hline & Harga & ,096 & 100 & 101 & ,958 & ,341 \\
\hline
\end{tabular}

a. Dependent Variable: RES2

Sumber : Data SPSS, 2021

Dari tabel 7 Uji Gletjer menunjukkan nilai yang signifikan $>0,05$ yaitu kualitas produk adalah $(0,158)$, kualitas pelayanan $(0,820)$, dan harga $(0,341)$ bahwa tidak terjadi masalah heteroskedastisitas.

\section{Hasil Analisis Data Penelitian Model Penelitian}

Pengujian hipotesis yang digunakan dalam penelitian ini adalah Analisi Regresi Linier Berganda, dengan model regrei yang digunakan sebagai berikut: 


\section{Tabel 8. Hasil Analisis Regresi Linear Berganda}

Coefficients $^{\mathbf{a}}$

\begin{tabular}{|c|c|c|c|c|c|c|}
\hline \multirow{2}{*}{\multicolumn{2}{|c|}{ Model }} & \multicolumn{2}{|c|}{ Unstandardized Coefficients } & \multirow{2}{*}{$\begin{array}{c}\text { Standardized } \\
\text { Coefficients } \\
\text { Beta }\end{array}$} & \multirow[b]{2}{*}{$\mathrm{t}$} & \multirow[b]{2}{*}{ Sig. } \\
\hline & & B & Std. Error & & & \\
\hline \multirow[t]{4}{*}{1} & (Constant) & 24,197 & 5,708 & & 4,239 & $<, 001$ \\
\hline & KualitasProduk &,- 127 &, 178 &,- 076 &,- 710 &, 480 \\
\hline & KualitasPelayanan &, 011 & .171 &, 007 &, 062 & 951 \\
\hline & Harga &,- 017 & 183 &,- 010 &,- 091 & 928 \\
\hline
\end{tabular}

a. Dependent Variable: KeputusanPembelian

Sumber : Data SPSS, 2021

$$
Y=24,197+-0,127 X 1+0,011 X 2+-0,017 X 3+e
$$

Penjelasan persamaan dari Tabel 8 sebagai berikut :

1. Konstanta sebesar 24,197 menyatakan bahwa jika variable independent dianggap konstan, maka nilai Keputusan Pembelian adalah sebesar 24,197.

2. Variabel Kualitas Produk $\left(\mathrm{X}_{1}\right)$ mempunyai nilai koefisien regresi sebesar $-0,127$ bertanda negative yang artinya setiap penambahan satu-satuan variable Kualitas Produk akan menurunkan Keputusan Pembelian sebesar -0,127.

3. Variabel Kualitas Pelayanan $\left(\mathrm{X}_{2}\right)$ mempunyai nilai koefisien regresi sebesar 0,011 bertanda positif yang artinya setiap penambahan satu-satuan variabel Kualitas Pelayanan akan meningkatkan Keputusan Pembelian sebesar 0,011.

4. Variabel Harga $\left(\mathrm{X}_{3}\right)$ mempunyai nilai koefisien regresi sebesar $-0,017$ bertanda negative yang artinya setiap penambahan satu-satuan variabel Harga akan menurunkan Keputusan Pembelian sebesar $-0,017$.

\section{Koefisien Determinasi Hipotesis}

Berikut hasil koefisien determinasi yaitu:

\section{Tabel 9. Uji Koefisien Determinasi}

\begin{tabular}{|c|c|c|c|c|}
\hline \multicolumn{5}{|c|}{ Model Summary } \\
\hline Model & $\mathrm{R}$ & R Square & $\begin{array}{l}\text { Adjusted R } \\
\text { Square }\end{array}$ & $\begin{array}{l}\text { Std. Error of } \\
\text { the Estimate }\end{array}$ \\
\hline 1 &, $075^{a}$ &, 006 &,- 028 & 4,353 \\
\hline
\end{tabular}

a. Predictors: (Constant), Harga, KualitasPelayanan, KualitasProduk

Sumber : Data SPSS, 2021

Tabel 9 Merupakan hasil Uji korefisien Determinasi yang memperoleh nilai Adjusted R Square negatif sebesar $-0,028(-2,8 \%)$ sehingga dianggap 0 , atau variabel bebas sama sekali tidak mampu menjelaskan varians dari variabel terikatnya.

\section{Pengujian Hipotesis Secara Simultan (Uji F)}

Berikut adalah hasil pengujian hipotesis secara simultan yaitu : 


\section{Tabel 10. Uji Simultan (Uji F)}

\begin{tabular}{|c|c|c|c|c|c|c|}
\hline \multicolumn{7}{|c|}{ ANOVA $^{a}$} \\
\hline Model & & $\begin{array}{l}\text { Sum of } \\
\text { Squares }\end{array}$ & df & Mean Square & $\mathrm{F}$ & Sig. \\
\hline \multirow[t]{3}{*}{1} & Regression & 9,561 & 3 & 3,187 & ,168 &, $918^{b}$ \\
\hline & Residual & 1686,396 & 89 & 18,948 & & \\
\hline & Total & 1695,957 & 92 & & & \\
\hline
\end{tabular}

Sumber : Data SPSS, 2021

Berdasarkan Tabel 10 dapat dilihat bahwa df pembilang $=3$, df penyebut $=89$ dan taraf signifikan $\alpha=$ 0,05 sehingga diperoleh hasil $\mathrm{F}_{\text {hitung }}=0,168<\mathrm{F}_{\text {tabel }} 2,71$ dan probabilitas signifikansi 0,918 $>0,05$. Dapat disimpulkan bahwa $\mathrm{H}_{0}$ diterima dan $\mathrm{H}_{\mathrm{a}}$ ditolak yaitu secara simultan Kualitas Produk, Kualitas Pelayanan dan Harga tidak berpengaruh signifikan terhadap variable Keputusan Pembelian mobil Mitsubishi PT. Sardana Indah Berlian Motor Medan.

\section{Pengujian Hipotesis Secara Parsial (Uji t)}

Berikut adalah hasil pengujian hipotesis secara Parsial yaitu :

\begin{tabular}{|c|c|c|c|c|c|c|}
\hline \multicolumn{7}{|c|}{$\begin{array}{l}\text { Tabel 11. Uji Parsial (Uji t) } \\
\text { Coefficients }^{a}\end{array}$} \\
\hline \multirow[b]{2}{*}{ Model } & & \multicolumn{2}{|c|}{ Unstandardized Coefficients } & \multirow{2}{*}{$\begin{array}{l}\text { Standardized } \\
\text { Coefficients } \\
\text { Beta }\end{array}$} & \multirow[b]{2}{*}{$t$} & \multirow[b]{2}{*}{ Sig. } \\
\hline & & B & Std. Error & & & \\
\hline \multirow[t]{4}{*}{1} & (Constant) & 24,197 & 5,708 & & 4,239 & $<, 001$ \\
\hline & KualitasProduk &,- 127 &, 178 &,- 076 &,- 710 &, 480 \\
\hline & KualitasPelayanan &, 011 &, 171 &, 007 &, 062 & 951 \\
\hline & Harga &,- 017 & 183 &,- 010 &,- 091 & 928 \\
\hline
\end{tabular}

a. Dependent Variable: KeputusanPembelian

Sumber : Data SPSS, 2021

Berdasarkan Tabel 11 maka Nilai tabel untuk probabilitas 0,05 pada derajat bebas (df) $=89$ adalah sebesar 1,987. Dengan demikian hasil uji hipotesis secara parsial dapat dijelaskan sebagai berikut :

1. Pengujian hipotesis secara parsial diperoleh nilai $t_{\text {hitung }}-0,710<1,987$ dan signifikansi yang diperoleh $0,480>0,05$, berarti bahwa $\mathrm{H}_{0}$ diterima dan $\mathrm{H}_{\mathrm{a}}$ ditolak yaitu secara parsial Kualitas Produk tidak berpengaruh signifikan terhadap Keputusan Pembelian mobil Mitsubishi PT. Sardana Indah Berlian Motor Medan.

2. Pengujian hipotesis secara parsial diperoleh nilai $t_{\text {hitung }}-0,062<1,987$ dan signifikansi yang diperoleh $0,951>0,05$, berarti bahwa $\mathrm{H}_{0}$ diterima dan $\mathrm{H}_{\mathrm{a}}$ ditolak yaitu secara parsial Kualitas Pelayanan tidak berpengaruh signifikan terhadap Keputusan Pembelian mobil Mitsubishi PT. Sardana Indah Berlian Motor Medan.

3. Pengujian hipotesis secara parsial diperoleh nilai $t_{\text {hitung }}-0,91<1,987$ dan signifikansi yang diperoleh $0,928>0,05$, berarti bahwa $\mathrm{H}_{0}$ diterima dan $\mathrm{H}_{\mathrm{a}}$ ditolak yaitu secara parsial Harga tidak berpengaruh signifikan terhadap Keputusan Pembelian mobil Mitsubishi PT. Sardana Indah Berlian Motor Medan. 


\section{Pembahasan}

Pengaruh Kualitas Produk terhadap Keputusan Pembelian Mobil Mitsubishi PT. Sardana Indah Berlian Motor

Menurut Tjiptono (2012), kualitas produk adalah tingkat mutu yang diharapkan dan pengendalian keragaman dalam mencapai mutu tersebut untuk memenuhi kebutuhan konsumen.

Pengujian hipotesis secara parsial diperoleh nilai $t_{\text {hitung }}-0,710<1,987$ dan signifikansi yang diperoleh $0,480>0,05$, berarti bahwa $\mathrm{H}_{0}$ diterima dan $\mathrm{H}_{\mathrm{a}}$ ditolak yaitu secara parsial Kualitas Produk tidak berpengaruh signifikan terhadap Keputusan Pembelian mobil Mitsubishi PT. Sardana Indah Berlian Motor Medan. Berdasarkan hasil penelitian, dapat disimpulkan bahwa penurunan penjualan mobil Mitsubishi dari PT. Sardana Indah Berlian Motor Medan tidak memiliki hubungan dengan kualitas produknya melainkan karena faktor-faktor lain yang tidak diteliti oleh peneliti.

\section{Pengaruh Kualitas Pelayanan terhadap Keputusan Pembelian Mobil Mitsubishi PT. Sardana Indah Berlian Motor}

Menurut Rambat Lupiyadi (2012), kualitas layanan adalah seberapa jauh perbedaan antara kenyataan dan harapan pelanggan atas layanan yang mereka terima/peroleh. Kualitas pelayanan harus dimulai dari kebutuhan pelanggan/nasabah dan berakhir dengankepuasan pelanggan serta dapat mempengaruhi dari loyalitas pelanggan/nasabah.

Pengujian hipotesis secara parsial diperoleh nilai thitung $-0,062<1,987$ dan signifikansi yang diperoleh $0,951>0,05$, berarti bahwa $\mathrm{H}_{0}$ diterima dan $\mathrm{H}_{\mathrm{a}}$ ditolak yaitu secara parsial Kualitas Pelayanan tidak berpengaruh signifikan terhadap Keputusan Pembelian mobil Mitsubishi PT. Sardana Indah Berlian Motor Medan. Berdasarkan hasil penelitian, dapat disimpulkan bahwa penurunan penjualan mobil Mitsubishi dari PT. Sardana Indah Berlian Motor Medan tidak memiliki hubungan dengan kualitas pelayanannya melainkan karena faktor-faktor lain yang tidak diteliti oleh peneliti.

\section{Pengaruh Harga terhadap Keputusan Pembelian Mobil Mitsubishi PT. Sardana Indah Berlian Motor}

Menurut Kotler dan Armstrong (2013:314), Harga adalah sejumlah uang yang dibebankan atas suatu produk atau jasa atau jumlah dari nilai yang ditukar konsumen atas manfaat-manfaat karena memiliki atau menggunakan produk atau jasa tersebut.

Pengujian hipotesis secara parsial diperoleh nilai $t_{\text {hitung }}-0,91<1,987$ dan signifikansi yang diperoleh $0,928>0,05$, berarti bahwa $\mathrm{H}_{0}$ diterima dan $\mathrm{H}_{\mathrm{a}}$ ditolak yaitu secara parsial Harga tidak berpengaruh signifikan terhadap Keputusan Pembelian mobil Mitsubishi PT. Sardana Indah Berlian Motor Medan. Berdasarkan hasil penelitian, dapat disimpulkan bahwa penurunan penjualan mobil Mitsubishi dari PT. Sardana Indah Berlian Motor Medan tidak memiliki hubungan dengan harga produknya melainkan karena faktor-faktor lain yang tidak diteliti oleh peneliti.

\section{KESIMPULAN}

Kesimpulan dari hasil penelitian ini adalah pengujian hipotesis secara parsial diperoleh nilai $t_{\text {hitung }}$ $0,710<1,987$ dan signifikansi yang diperoleh $0,480>0,05$, berarti bahwa $\mathrm{H}_{0}$ diterima dan $\mathrm{H}_{\mathrm{a}}$ ditolak yaitu secara parsial Kualitas Produk tidak berpengaruh signifikan terhadap Keputusan Pembelian mobil Mitsubishi PT. Sardana Indah Berlian Motor Medan. Pengujian hipotesis secara parsial diperoleh nilai $t_{\text {hitung }}$ $-0,062<1,987$ dan signifikansi yang diperoleh $0,951>0,05$, berarti bahwa $\mathrm{H}_{0}$ diterima dan $\mathrm{H}_{\mathrm{a}}$ ditolak yaitu secara parsial Kualitas Pelayanan tidak berpengaruh signifikan terhadap Keputusan Pembelian mobil Mitsubishi PT. Sardana Indah Berlian Motor Medan. Pengujian hipotesis secara parsial diperoleh nilai $t_{\text {hitung }}$ $-0,91<1,987$ dan signifikansi yang diperoleh $0,928>0,05$, berarti bahwa $\mathrm{H}_{0}$ diterima dan $\mathrm{H}_{\mathrm{a}}$ ditolak yaitu secara parsial Harga tidak berpengaruh signifikan terhadap Keputusan Pembelian mobil Mitsubishi PT. Sardana Indah Berlian Motor Medan. Pengujian hipotesis secara simultan diperoleh hasil $\mathrm{F}_{\text {hitung }}=0,168<$ $\mathrm{F}_{\text {tabel }} 2,71$ dan probabilitas signifikansi 0,918 $>0,05$. Dapat disimpulkan bahwa $\mathrm{H}_{0}$ diterima dan $\mathrm{H}_{\mathrm{a}}$ ditolak yaitu secara simultan Kualitas Produk, Kualitas Pelayanan dan Harga tidak berpengaruh signifikan terhadap variable Keputusan Pembelian mobil Mitsubishi PT. Sardana Indah Berlian Motor Medan. Berdasarkan hasil penelitian ini maka peneliti dapat menyatakan bahwa saat ini kualitas produk, kualitas pelayanan dan 
harga bukan menjadi alasan menurunnya penjualan mobil Mitsubishi, sehingga peneliti menyarankan agar perusahaan untuk memperhatikan pengaruh merk, promosi, daya beli, sosial, dsb. Untuk penelitian selanjutnya, peneliti menyarankan untuk meneliti variable independen lain diluar dari variable kualitas produk, kualitas pelayanan dan harga, seperti variabel merk, promosi, daya beli, sosial.

\section{REFERENSI}

2, D. P. (2021, January 15). Pengertian Harga. Retrieved from www.dosenpendidikan.co.id.

Arhando, P. (2019, Oktober 10). Ini Kenapa Orang Indonesia Suka Beli Mobil Walau Gak Punya Garasi . Retrieved from lifepal.co.id: https://ifepal.co.id/media/mobil-jadi-penanda-status-sosial-orangindonesia/

Harga: Pengertian, Fungsi, Tujuan serta Jenis-jenis harga. (n.d.). Retrieved from www.porosilmu.com. Hestanto. (2020). Keputusan Pembelian. Retrieved from www.hestanto.web.id: https://www.hestanto.web.id/keputusan-pembelian/

Indonesia, W. b. (2020, September 3). Transportasi. Retrieved from wikipedia: https://id.wikipedia.org/wiki/Transportasi

Kurniawan, R. (2020, Desember 21). Jelang Akhir Tahun, Ini 5 Besar Merek Mobil Terlaris di Indonesia. (A. Kurniawan, Editor) Retrieved from kompas.com: https://otomotif.kompas.com/read/2020/12/21/072200015/jelang-akhir-tahun-ini-5-besar-merekmobil-terlaris-di-indonesia?page $=$ all

Mengapa Memiliki Mobil Di Indonesia Dianggap Penting. (2019, Agustus 28). Retrieved from simasinsurtech.com: https://simasinsurtech.com/mengapa-memiliki-mobil-di-indonesia-dianggappenting/

Riadi, M. (2020, Mei 30). Keputusan Pembelian (Pengertian, Dimensi, Jenis dan Proses Tahapan) . Retrieved from www.kajianpustaka.com: https://www.kajianpustaka.com/2020/05/keputusanpembelian-pengertian-dimensi-jenis-dan-proses-tahapan-pembelian.html?m=1

Sugiyono. (2015). Statistik Untuk Penelitian.

Surjaweni, W. (2015). SPSS untuk Penelitian.

Verawati. (2019). Pengaruh Motivasi dan Sikap Konsumen Terhadap Keputusan Pembelian Produk Kesehatan di PT. Jaco Nusantara Mandiri Medan. Medan.

purbowati, D. (2021). Metode Penelitian Kualitatif dan Kuantitatif: Mengenal Penelitian Ilmiah. Retrieved from https://akupintar.id. 